\title{
PENGARUH ETOS KERJA ISLAM TERHADAP KEPUASAN KERJA KARYAWAN PADA WAROENG STEAK \& SHAKE DI SURABAYA
}

\author{
Harjanto Saputro \\ Mahasiswa Program Studi S-1 Ekonomi Islam - Fakultas Ekonomi dan Bisnis - Universitas \\ Airlangga \\ Ari Prasetyo \\ Departemen Ekonomi Syariah - Fakultas Ekonomi dan Bisnis - Universitas Airlangga \\ Email: ariffeunair@yahoo.co.id
}

\begin{abstract}
This research was aimed to investigate the effect of Islamic work ethics to the employee Satisfaction on Waroeng Steak \& Shake in Surabaya. This study used questionnaires in primary data collection and quantitative approaches. Experiments were done using simple linear regression, where the dependent variable $(Y)$ is the employee work satisfaction and the independent variable $(X)$ is Islamic work ethics. The research sample were taken by census. The research sample was 33 employees working in Waroeng Steak \& Shake Surabaya.

Based on the findings, it obtained simple linear regression equation : $Y=0,929+$ $0,684 X$. The magnitude of the influence of Islamic work ethics to the employees work satisfaction on Waroeng Steak \& Shake in Surabaya is the R2 value of 0,423 (42,3\%). The result show that employee work satisfaction on Waroeng Steak \& Shake in Surabaya significantly affect by Islamic work ethics.
\end{abstract}

\section{Keyword : Islamic Work Ethics, Employee Work Satisfaction}

\section{PENDAHULUAN}

\section{A. Latar Belakang}

Peran Sumber daya manusia dalam memajukan suatu perusahaan sangatlah penting. Salah satu pendekatan dalam peningkatan kualitas sumber daya manusia adalah melalui pendekatan agama. Dalam agama Islam terdapat konsep etos kerja Islami yang berlandaskan Al-QU'ran serta contoh dari Nabi Muhammad SAW. Islam sebagai agama yang sempurna, sistem keimanan dan aqidah yang diyakini oleh para pemeluknya yaitu muslim, juga mengatur mengenai etos kerja, mendorong dan mengutus umatnya untuk memiliki semangat kerja dan beramal, tanpa mengeluh yang menunjukkan adanya kepuasan bagi diri sendiri.

Islam sebagai salah satu agama samawi telah menekankan kepada umat untuk bekerja. Sebagaimana dalam sabda-Nya bahwa "Bekerjalah untuk duniamu seakan- akan kamu hidup selamanaya dan beribadahlah untuk akhiratmu seakan-akan kamu mati besok". Mangkunegara berpendapat bahwa sebenarnya kitab suci Al-Qur'an dari agama Islam mengajarkan unsur-unsur tersebut, yaitu seperti manusia harus bekerja keras, sebagaimana firman-firman Allah SWT dalam surat Al-Qashash ayat 77 : 


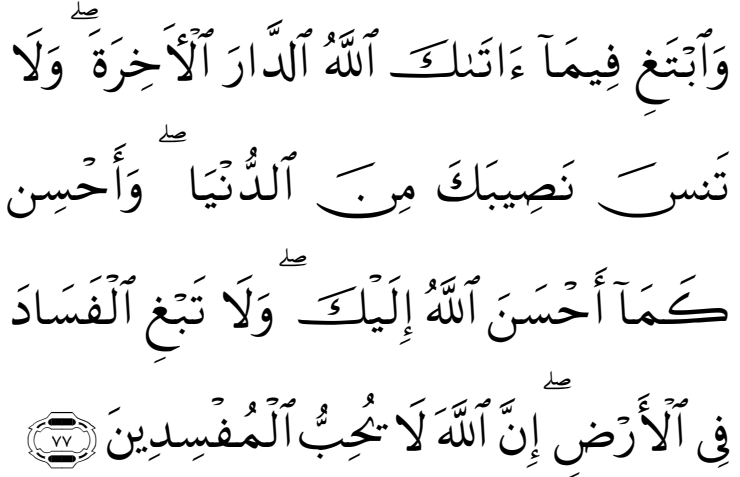

wabtaghi fimā ātākallāhu ddāra Iākhirata walā tansa naşibaka mina ddunyā wa-ahsin kamā ahsanallāhu ilayka walā tabghi Ifasāda fi l-ardi innallāha lā yuhibbu Imufsidīn

Artinya : "Dan carilah pada apa yang telah dianugerahkan Allah kepadamu (kebahagiaan) negeri akhirat, dan janganlah kamu melupakan bahagianmu dari (kenikmatan) duniawi dan berbuat baiklah (kepada orang lain) sebagaimana Allah telah berbuat baik, kepadamu, dan janganlah kamu berbuat kerusakan di (muka) bumi. Sesungguhnya Allah tidak menyukai orang-orang yang berbuat kerusakan." (DEPAG, 2012). Ali dan Owaihan (2008) mengatakan bahwa sejak awal masa muslim, khususnya umat muslim telah menawarkan pandangan pada pekerjaan dan telah merumuskan secara jelas mengenai konsep etos kerja. Etos kerja erat kaitannya dengan nilai-nilai kerja yang diyakini dan dimiliki oleh seorang karyawan, yang nantinya mempengaruhi sikap karyawan dalam bekerja.
Kepuasan kerja atau dalam arti yang lebih khusus yaitu kepuasan karyawan dalam bekerja merupakan suatu pengertian yang didefinisikan oleh Brown and Leigh (1996:123) sebagai keadaan emosional yang positif sebagai hasil dari penilaian karyawan terhadap situasi kerjanya. Dalam kehidupan organisasi, seringkali kepuasan kerja digunakan sebagai dasar ukuran tingkat kematangan organisasi. Salah satu gejala yang menyebabkan kurang baiknya kondisi kerja suatu organisasi adalah rendahnya kepuasan kerja. Sebaliknya, kepuasan kerja yang lebih tinggi merupakan tanda bahwa organisasi dikelola dengan baik dan pada dasarnya merupakan hasil dari manajemen yang efektif. Ada kecenderungan yang beranggapan bahwa apabila kondisi kerja, sosial, dan lainnya kurang memadai, maka akan muncul ketidakpuasan yang pada gilirannya merupakan suatu keadaan yang tidak diinginkan baik oleh karyawan maupun oleh manajemen.

Sebagai rumah makan yang memiliki aroma ke-Islaman yang cukup kental, seharusnya rumah makan ini menerapkan nilai-nilai Islam untuk para karyawannya. Hal tersebut dibuktikan dari agenda yang telah disusun oleh pemilik rumah makan ini yaitu diadakannya tausiyah bagi karyawankaryawan yang bekerja di Waroeng Steak \& Shake. Tujuan dilakukannya tausiyah khusus bagi para karyawan tentunya untuk membentuk moral para karyawan agar berlaku lebih baik sesuai dengan 
ajaran Islam. Hal ini juga merupakan salah satu strategi pemilik rumah makan ini agar dapat memenuhi kepuasan para karyawannya. Dengan asumsi bahwa, apabila kepuasan karyawan dapat terpenuhi, maka akan timbul semangat dalam bekerja.

Dari latar belakang di atas dapat dijelaskan, bahwa dalam pemenuhan kepuasan kerja dipengaruhi faktor etos kerja Islam. Hal ini dikarenakan dengan etos kerja Islam yang baik pada karyawan akan membentuk sumber daya yang lebih baik, yang ikhlas dalam menerima kondisi dalam lingkungan pekerjaan. Penelitian ini bertujuan untuk mengetahui pengaruh etos kerja Islam terhadap kepuasan kerja karyawan pada Waroeng Steak \& Shake Surabaya.

II. LANDASAN

TEORI

DAN

\section{PENGEMBANGAN HIPOTESIS}

\section{A. Etos Kerja}

Kata etos berasal dari bahasa Yunani (ethos) yang memberikan arti sikap, kepribadian, watak, karakter serta keyakinan atas sesuatu. Ełos dibentuk oleh berbagai kebiasaan, pengaruh budaya, serta sistem nilai yang diyakininya. Menurut Kamus Umum Bahasa Indonesia, etos adalah ilmu pengetahuan tentang asas-asas akhlak (moral). Ełos pada umumnya didefinisikan sebagai suatu usaha yang sistematis dengan menggunakan rasio untuk menafsirkan pengalaman moral individual dan sosial sehingga, dapat menetapkan aturan untuk mengendalikan perilaku manusia serta nilai-nilai yang berbobot untuk dapat dijadikan sasaran dalam hidup. Menurut Hamzah (1983), etos ialah ilmu yang menyelidiki mana yang baik dan mana yang buruk dan memperlihatkan amal perbuatan manusia sejauh yang dapat diketahui oleh akal pikiran. Menurut Herman (2004), Ełos dapat dijelaskan dengan membedakan dengan tiga arti, yaitu :

1. IImu tentang apa yang baik dan apa yang buruk dan tentang hak dan kewajiban moral (akhlak).

2. Kumpulan asas atau nilai yang berkenaan dengan akhlak.

3. Nilai mengenai benar dan salah yang dianut suatu golongan atau masyarakat.

Dari ratusan teori sukses yang beredar di masyarakat sekarang ini, Sinamo (2005) menyederhanakannya menjadi empat pilar teori utama. Keempat pilar inilah yang sesungguhnya bertanggung jawab menopang semua jenis dan sistem keberhasilan yang berkelanjutan (sustainable success system) pada semua tingkatan. Keempat elemen itu lalu dikonstruksikan dalam sebuah konsep besar yang disebutnya sebagai Catur Dharma Mahardika (bahasa Sansekerta) yang berarti Empat Darma Keberhasilan Utama, yaitu:

1. Mencetak prestasi dengan motivasi superior.

2. Membangun masa depan dengan kepemimpinan visioner.

3. Menciptakan nilai baru dengan inovasi kreatif. 
4. Meningkatkan mutu dengan keunggulan insani.

Keempat darma ini kemudian dirumuskan menjadi enam aspek etos kerja sebagal berikut:

a. Kerja adalah rahmat. Apa pun pekerjaan kita, entah pengusaha, pegawai kantor, sampai buruh kasar sekalipun, adalah rahmat dari Tuhan. Anugerah itu kita terima tanpa syarat, seperti halnya menghirup oksigen dan udara tanpa biaya sepeser pun.

b. Kerja adalah amanah. Kerja merupakan titipan berharga yang dipercayakan pada kita sehingga secara moral kita harus bekerja dengan benar dan penuh tanggung jawab. Etos ini membuat kita bisa bekerja sepenuh hati dan menjauhi tin dakan tercela, misalnya korupsi dalam berbagai bentuknya.

c. Kerja adalah panggilan. Kerja merupakan suatu darma yang sesuai dengan panggilan jiwa sehingga kita mampu bekerja dengan penuh integritas. Jadi, jika pekerjaan atau profesi disadari sebagai panggilan, kita bisa berucap pada diri sendiri, "I'm doing my best". Dengan begitu kita tidak akan merasa puas jika hasil karya kita kurang baik mutunya.

d. Kerja adalah aktualisasi. Pekerjaan adalah sarana bagi kita untuk mencapai hakikat manusia yang tertinggi, sehingga kita akan bekerja keras dengan penuh semangat. Apa pun pekerjaan kita, entah dokter, akuntan, ahli hukum, semuanya bentuk aktualisasi diri. Meski kadang membuat kita lelah, bekerja tetap merupakan cara terbaik untuk mengembangkan potensi diri dan membuat kita merasa "ada". Bagaimanapun sibuk bekerja jauh lebih menyenangkan daripada duduk termenung tanpa pekerjaan.

e. Kerja adalah pelayanan. Manusia bekerja bukan hanya untuk memenuhi kebutuhannya sendiri saja tetapi untuk melayani, sehingga harus bekerja dengan sempurna dan penuh kerendahan hati. Apapun pekerjaan kita, pedagang, polisi, bahkan penjaga mercusuar, semuanya bisa dimaknai sebagai pengabdian kepada sesama.

f. Kerja adalah ibadah. Bekerja merupakan bentuk bakti dan ketakwaan kepada Tuhan, sehingga melalui pekerjaan manusia mengarahkan dirinya pada tujuan agung Sang Pencipta dalam pengabdian. Kesadaran ini pada gilirannya akan membuat kita bisa bekerja secara ikhlas, bukan demi mencari uang atau jabatan semata.

B. Etos Kerja Islam

Etos kerja Islam menurut Asifudin (2004:234) merupakan karakter dan kebiasaan manusia berkenaan dengan kerja, terpancar dari sistem keimanan/aqidah Islam yang merupakan sikap hidup mendasar terhadapnya. Menurut Tasmara (2002:26), etos kerja Islam adalah suatu upaya yang sungguh-sungguh, dengan 
mengerahkan seluruh aset, pikiran, dan zikirnya untuk mengaktualisasikan atau menampakan arti dirinya sebagai hamba Allah yang harus menundukan dunia dan menempatkan dirinya sebagai bagian dari masyarakat yang terbaik (khairul ummah) atau dengan kata lain dapat juga kita katakan bahwa hanya dengan bekerja manusia itu memanusiakan dirinya. Ełos kerja Islami adalah akhlak dalam

bekerja sesuai dengan nilai-nilai islam sehingga dalam melaksanakannya tidak perlu lagi di pikir-pikir karena jiwanya sudah meyakini sebagai sesuatu yang baik dan benar.

Etos kerja Islam pada hakekatnya merupakan bagian dari konsep Islam tentang manusia karena etos kerja adalah bagian dari proses eksistensi diri manusia dalam lapangan kehidupannya yang amat luas dan komplek. Ełos kerja merupakan nilainilai yang membentuk kepribadian seseorang dalam bekerja. Ełos kerja pada hakekatnya di bentuk dan dipengaruhi oleh sistem nilai yang dianut seseorang dalam bekerja. Yang kemudian membentuk semangat yang membedakannya antara yang satu dengan yang lain. Ełos kerja Islam dengan demikian merupakan refleksi pribadi seorang kholifah yang bekerja dengan bertumpu pada kemampuan konseptual yang dimilikinya yang bersifat kreatif dan inovatif (Azizi, 2005:35).

\section{Islam Dan Ełos Kerja}

Menurut Ahmad (2001:16) Islam adalah agama yang menghargai kerja keras. Kenyataan ini dapat terlihat dari serangkaian firman Allah dalam AlQur'an yang sangat menekankan arti penting, sebagaimana yang tercantum dalam surat Az-Zumar ayat 39 sebagai berikut:

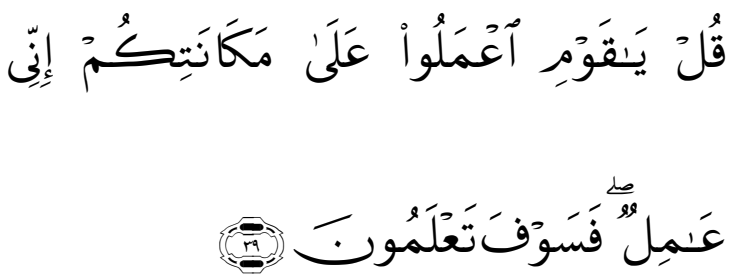

Qul yā qaumi'malū 'alā makānatikum innī 'āmil, fa saufa ta'lamūn

Artinya : "Katakanlah, hai kaumku, bekerjalah sesuai dengan keadaanmu, sesungguhnya

Aku akan bekerja (pula) maka kelak kamu akan mengetahui." (DEPAG, 2012)

Dalam ayat tersebut dapat diambil pelajaran sebagai berikut :

1. Al-Quran adalah petunjuk yang paling sempurna bagi manusia.

2. Setiap makhluk akan mati dan di akhirat akan dihisab tentang amalanamalannya. Sekalipun manusia itu banyak dosanya, dilarang berputus-asa terhadap rahmat Allah.

Ełos kerja islami itu sendiri berasal dari AlQur'an dan Hadits Nabi Muhammad SAW, yang mengajarkan bahwa dengan bekerja keras yang disebabkan karena telah berbuat dosa akan diampuni oleh Allah SWT dan tidak ada makanan yang 
lebih baik dibandingkan apa yang dimakan dari hasil jerih payahnya atau kerja kerasnya. Ełos kerja Islam memberikan pandangan mengenai dedikasi yang tinggi dalam bekerja keras sebagai sebuah kewajiban yang wajib. Usaha yang cukup haruslah menjadi bagian dari kerja yang dilakukan seseorang, yang terlihat sebagai kewajiban individu yang cakap (Tasmara,

2002:25).

Menurut Tasmara (2002:26) etos kerja Islam menekankan pada kerja sama dalam bekerja, dan konsep konsultasi yang terlihat sebagai jalan untuk mengatasi rintangan atau masalah dan menghindari kesalahan. Hubungan sosial dalam bekerja merupakan pendorong yang bertujuan untuk mempertemukan kebutuhan seseorang dan membuat keseimbangan antara kebutuhan individu dan kehidupan sosial. Tasmara mengatakan bahwa semangat kerja dalam Islam kaitannya dengan niat semata-mata bahwa bekerja merupakan kewajiban agama dalam rangka menggapai ridha Allah, sebab itulah dinamakan jihad fiisabilillah. Kunci etos kerja Islam adalah memberikan kebebasan individu untuk memilih sektor kerja menurut kemampuannya. Setiap orang bebas mempergunakan haknya untuk memilih mana yang terbaik untuk melakukan suatu kebajikan. Kebebasan itu telah menjadi modal awal setiap individu untuk memperkuat etos kerja.

\section{B. Terbentuknya Etos Kerja Islam}

Salah satu karateristik yang melekat pada etos kerja manusia, ia merupakan pancaran dari sikap hidup mendasar pemiliknya terhadap kerja. Mitsou dalam Asifudin (2004:30) menerangkan bahwa dorongan kebutuhan dan aktualisasi diri, nilai-nilai yang dianut, keyakinan atau ajaranagama tertentu dapat pula menjadi sesuatu yang berperan dalam proses terbentuknya sikap hidup mendasar.

Penjelasan di atas memberikan pemahaman kita bahwa latar belakang keyakinan dan motivasi berlainan, maka cara terbentunya etos kerja yang bersaungkut paut dengan agama (non agama) dengan sendirinya mengandung perbedaan dengan cara terbentuknya etos kerja yang berbasis ajaran agama, dalam hal ini etos kerja islami. Gambaran terbentuknya etos kerja islami, sebagaimana yang dipaparkan oleh Asifudin (2004:31) Berikut adalah yang bersifat islami secara sederhana dapat digambarkan di bawah ini:

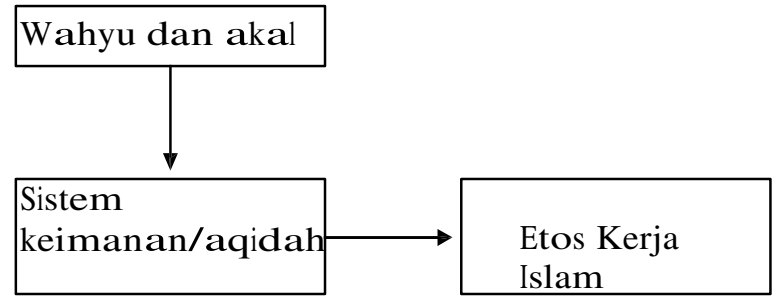

Gambar 1.

Paradigma terbentuknya etos kerja Islam

Etos kerja Islami terpancar dari sistem keimanan/aqidah Islam berkenaan 
dengan kerja. Aqidah ini terbentuk dari ajaran wahyu dan akal yang bekerja sama secara proporsional menurut fungsi masing-masing.

\section{Karakteristik Ełos Kerja Islam}

Menurut Asifudin (2004:101), ciri-ciri etos kerja Islam digali dan dirumuskan berdasarkan konsep iman dan amal shaleh dengan memberikan prioritas penekanan pada etos kerja Islam beserta prinsip-prinsip dasarnya sebagai fokus. Karena etos kerja apapun menurut Quran tidak dapat menjadi Islam bila tidak dilandaskan pada konsep iman dan amal shaleh. Lanjut Asifudin (2004:104) bahwa dari konsep iman, ilmu dan amal, dapat digali dan dirumuskan karakteristikkarakteristik etos kerja Islam:

\section{A. Kerja merupakan penjabaran Aqidah}

Manusia adalah makhluk yang dikendalikan oleh sesuatu yang bersifat batin dalam dirinya, bukan oleh fisik yang tampak. la terpengaruh dan diarahkan oleh keyakinan yang mengikatnya. Keyakinan tersebut bila telah tertanam mantap dalam hati, akan berusaha menyembul bersama kehendak pemiliknya. Faktor agama memang tidak menjadi syarat timbulnya etos kerja tinggi seseorang. Hal itu terbukti dengan banyaknya orang yang tidak beragama mempunyai etos kerja yang baik. Tetapi berdasarkan teori tersebut di atas, orang itu pasti memiliki keyakinan, pandangan atau sikap hidup tertentu menjadi pemancar bagi etos kerja yang baik tersebut. Jadi ajaran agama merupakan salah satu faktor yang menjadi sebab timbulnya keyakinan, pandangan, sikap hidup mendasar yang menyebabkan etos kerja tinggi manusia terwujud. Lanjut Asifudin (2004:224) ciri-ciri orang yang mengganggap bahwa kerja merupakan penjabaran dari aqidah adalah;

1. Dapat menerima kenyataan berkenaan dengan diri sendiri, orang lain, dan alam.

2. Berperilaku wajar tidak dibuat-buat.

3. Berpendirian teguh dan tidak mudah terpengaruh.

4. Konsentrasi perbuatan tidak pada ego, melainkan pada kewajiban dan rasa tanggung jawab.

5. Memiliki kesegaran apresiasi terhadap alam dan kehidupan.

6. Mempunyai kehidupan motivasi yang terutama digerakan oleh motivasi ibadah dan hasrat memperoleh kehidupan surgawi di akhirat kelak.

B. Kerja Dilandasi IImu

Ciri-ciri orang yang mengganggap bahwa kerja dilandasi ilmu adalah (Asifudin:225):

1. Pernah atau sering mengalami pengalaman puncak.

2. Mampu membedakan antara tujuan benar dan salah, baik dan buruk.

3. Menyukai efisiensi dan efektivitas kerja.

4. Mempunyai disiplin pribadi.

C. Kerja dengan Meneladani Sifat-sifat llahi serta Mengikuti Petunjuk-petunjukNya 
Ciri-ciri orang yang mengganggap bahwa kerja dengan meneladani sifatsifat llahiah serta mengikuti petunjukpetunjukNya adalah (Asifudin:226) :

1. Memiliki jiwa sosial dan sifat demokratis.

2. Mengembangkan kreativitas.

3. Percaya pada potensi insani karunia Tuhan untuk melaksanakan tugasnya: bertawakkal kepada Allah SWT.

4. Mengembangkan sikap hidup kritis konstruktif.

\section{Kepuasan Kerja}

Menurut Wiyono (2005) kepuasan adalah tingkat adalah tingkat keadaan yang dirasakan seseorang yang mempunyai hasil dari membandingkan penampilan atau outcome produk yang dirasakan dalam hubungannya dengan harapan seseorang.

Menurut Wexley dan Yukl (1997) kepuasan kerja secara umum dapat diberi batasan sebagai perasaan seseorang terhadap pekerjaannya. Kemudian oleh Vroom (1964) dikatakan bahwa kepuasan kerja merupakan penilaian dari perkerja yaitu seberapa jauh pekerjaannya secara keseluruhan memuaskan kebutuhannya. Tiffin (1958) berpendapat bahwa kepuasan kerja berhubungan erat dengan sikap dari karyawan terhadap pekerjaannya sendiri, situasi kerja, kerjasama antar pimpinan dengan sesama karyawan.
Menurut As'ad (2000) dikutip pengertian kepuasan kerja menurut Blum yang mengemukakan bahwa kepuasan kerja merupakan sikap umum dari beberapa sikap khusus dari beberapa faktor-faktor pekerjaan, penyesuaian diri dan hubungan individu diluar kerja.

Menurut Jewel L.N. dan Mac Siegall (1998) kepuasaan kerja, menggunakan 5 (lima) dimensi kepuasaan terhadap pekerjaan yaitu dari aspek pekerjaan itu sendiri, pengawasan, penggajian, kesempatan promosi, dan aspek rekan kerja sebagai faktor penentu kepuasaan kerja.

Menurut Hasibuan (2001) kepuasan kerja adalah sikap emosional yang menyenangkan dan mencinta pekerjaannya. Kepuasan kerja (job satisfaction) karyawan harus diciptakan sebaik-baiknya supaya moral kerja, dedikasi, kecintaan, dan kedisiplinan karyawan meningkat. Sikap ini dicerminkan oleh moral kerja, kedisiplinan, dan prestasi kerja. Kepuasan kerja dinikmati dalam pekerjaan, dan kombinasi dalam dan luar pekerjaan. Kepuasan kerja dalam perkerjaan adalah kepuasan kerja yang dinikmati dalam pekerjaan dengan memperoleh pujian hasil kerja, penempatan, perlakuan, peralatan, dan suasana lingkungan kerja yang baik. Karyawan yang lebih suka menikmati kepuasan kerja dalam pekerjaan akan lebih mengutamakan pekerjaannya daripada balas jasa walaupun balas jasa itu penting. 
1. Aspek-aspek Kepuasan Kerja

Menurut Sutrisno (2001) kepuasan kerja pada dasarnya adalah rasa aman (security feeling) dan mempunyai segi-segi yaitu segi sosial dan ekonomi (gaji dan jaminan sosial) dan segi sosial psikologi yaitu kesempatan untuk maju, kesempatan mendapatkan pekerjaan, berhubungan dengan masalah pengawasan, berhubungan dengan pergaulan antara karyawan dengan atasannya.

Menurut Wexley dan Yukl (1997) secara umum ada 3 (tiga) teori tentang kepuasan kerja yaitu :

1. Teori Pertentangan (Discrepancy Theory). Teori ini dipelopori oleh Porter (1961) dimana kepuasan ini diukur dengan menghitung selisih dari apa yang seharusnya dengan kenyataan yang ada (dirasakan). Kemudian Locke (1969) menyatakan

bahwa kepuasan atau ketidakpuasan terhadap beberapa aspek dari pekerjaan mencerminkan penimbangan atas dua nilai yaitu pertentangan yang dipersepsikan antara apa yang diinginkan seseorang individu dengan apa yang ia terima, dan pentingnya apa yang diinginkan individu.

2. Equity Theory. Pendahulu teori ini adalah Zeleznik (1958) dan dikembangkan oleh Adams (1963). Prinsip dari teori ini adalah bahwa puas atau tidaknya seseorang itu tergantung pada apakah ia measakan adanya keadilan (equity) atau tidak atas suatu situasi, diperoleh orang dengan cara membandingkan dirinya dengan orang lain. Bila perbandingan itu dianggap tidak seimbang tetapi menguntungkan, bisa menimbulkan kepuasan tetapi bisa pula tidak. Tetapi bila perbandingan itu tidak seimbang dan merugikan maka akan menimbulkan ketidakpuasan.

3. Two Factor Theory. Teori ini pertama kali dikembangkan oleh Hazberg (1969), Hazberg mempengaruhi sikap seseorang terhadap pekerjaannya menjadi dua kelompok yaitu kelompok satisfiers atau motivator dan kelompok dissatisfiers atau hygiene factors.

Satisfiers (Memotivator) atau intrinsic factor, job content dan motivator, adalah faktor-faktor atau situasi yang dibuktikan sebagai sumber kepuasan kerja terdiri dari : achievement, recognition, work it self, responsibility and advancement. Hadirnya faktor ini akan menimbulkan kepuasan tetapi tidak selamanya menimbulkan ketidakpuasan.

Dissatisfiers (hygiene factor) atau extrinsic factor, job content adalah faktor-faktot yang terbukti menjadi sumber ketidakpuasan yang terdiri dari : company policy and administration, supervision technical salary, interpersonal relation, working conditing, job security dan status.

2. Faktor-faktor yang Mempengaruhi Kepuasan Kerja

Kepuasan kerja bagi karyawan sangat diperlukan karena kepuasan kerja karyawan akan meningkatkan produktivitas. Adanya ketidakpuasan pada para karyawan dalam bekerja akan membawa akibat-akibat yang 
kurang menguntungkan baik bagi perusahaan maupun bagi karyawan itu sendiri.

Menurut Wexley dan Yukl (1997); Kepuasan kerja didefinisikan sebagai sikap menyenangkan yang dirasakan seseorang karyawan terhadap pekerjaan. Faktor-faktor yang mempengaruhi kepuasan kerja adalah:

1. Upah, meliputi :

a. Besarnya gaji yang diterima secara keseluruhan dengan mempertimbangkan upaya-upaya yang diberikan karyawan terhadap perusahaan.

b. Sistem pemberian gaji yang diterapkan oleh perusahaan. c. Kesesuaian gaji denan upaya yang telah dilakukan.

2. Pekerjaan itu sendiri, meliputi :

a. Kondisi sekitar tempat karyawan bekerja.

b. Kelengkapan saarana pekerjaan yag diberikan pihak perusahaan. C. Keamanan lingkungan kerja.

3. Pengawasan, meliputi :

a. Pemberian petunjuk yang sesuai dengan standar kerja. b. Penerapan peraturan kerja.
4. Peluang promosi, meliputi :
a. Kesempatan peningkatan kualitas.
b. Kesempatan mengembangkan karir.

5. Kelompok kerja, meliputi :

a. Hubungan dengan rekan kerja.

b. Kekompakan dengan rekan kerja.

C. Suasana yang ada dalam kelompok kerja.

6. Kondisi kerja, meliputi : a. Kesesuaian pekerjaan dengan kemampuan.

b. Jenis pekerjaan yang dirasa karyawan menarik dan menantang.

\section{E. Hipotesis}

Berdasarkan permasalahan yang telah dirumuskan, tujuan penelitian serta landasan teori yang telah disebutkan sebelumnya, maka hipotesis yang dapat dirumuskan dalam penelitian ini adalah etos kerja Islam mempunyai pengaruh terhadap kepuasan kerja karyawan pada Waroeng Steak \& Shake Surabaya.

\section{METODOLOGI PENELITIAN}

Pendekatan penelitian yang digunakan dalam penelitian ini adalah pendekatan kuantitatif, yang bertujuan untuk menguji hipotesis, dengan data yang terukur dan menghasilkan kesimpulan yang dapat digeneralisir. Langkah awal dalam melakukan penelitian kuantitatif dimulai dengan menentukan hipotesis, langkah selanjutnya membuat model analisis, indentifikasi variabel, definisi operasional, pengumpulan data (primer maupun sekunder) berdasarkan populasi dan sampel penelitian, serta melakukan analisis. Variabel yang digunakan dalam penelitian ini dapat diidentifikasikan menjadi 2 (dua) variabel, yaitu:

a. Variabel independen $(X)$, yaitu etos kerja Islam. b. Variabel dependen (Y), yaitu kepuasan kerja.

1. Definisi Operasional Variabel a. Etos Kerja Islam (X) 
Menurut Asifudin (2004:101), ciri-ciri etos kerja Islam digali dan dirumuskan berdasarkan konsep iman dan amal shaleh dengan memberikan prioritas penekanan pada etos kerja Islam beserta prinsip-prinsip dasarnya sebagai fokus. Karena etos kerja apapun menurut Quran tidak dapat menjadi Islam bila tidak dilandaskan pada konsep iman dan amal shaleh. Lanjut Asifudin (2004:104) bahwa dari konsep iman, ilmu dan amal, dapat digali dan dirumuskan karakteristikkarakteristik etos kerja Islam:

A. Kerja merupakan penjabaran aqidah, meliputi :

1. Dapat menerima kenyataan berkenaan dengan diri sendiri, orang lain, dan alam.

2. Berperilaku wajar tidak dibuat-buat.

3. Berpendirian teguh dan tidak mudah terpengaruh.

4. Konsentrasi perbuatan tidak pada ego, melainkan pada kewajiban dan rasa tanggung jawab.

5. Memiliki kesegaran apresiasi terhadap alam dan kehidupan.

6. Mempunyai kehidupan motivasi yang terutama digerakan oleh motivasi ibadah dan hasrat memperoleh kehidupan surgawi di akhirat kelak.

B. Kerja dilandasi ilmu, meliputi :

1. Pernah atau sering mengalami pengalaman puncak.

2. Mampu membedakan antara tujuan benar dan salah, baik dan buruk.

3. Menyukai efisiensi dan efektivitas kerja.
4. Mempunyai disiplin pribadi.

C. Kerja dengan meneladani sifat-sifat ilahi serta mengikuti petunjuk-petunjukNya, meliputi :

1. Memiliki jiwa sosial dan sifat demokratis.

2. Mengembangkan kreativitas.

3. Percaya pada potensi insani karunia Tuhan untuk melaksanakan tugasnya:

bertawakkal kepada Allah SWT.

4. Mengembangkan sikap hidup kritis konstruktif.

b. Kepuasan Kerja (Y)

Menurut Wexley dan Yukl (1997) Kepuasan kerja didefinisikan sebagai sikap menyenangkan yang dirasakan seseorang karyawan terhadap pekerjaan. Faktor-faktor yang mempengaruhi kepuasan kerja setelah disesuaikan adalah :

1. Upah, meliputi :

a. Besarnya gaji yang diterima secara keseluruhan dengan mempertimbangkan upaya-upaya yang diberikan karyawan terhadap perusahaan.

b. Sistem pemberian gaji yang diterapkan oleh perusahaan. c. Kesesuaian gaji dengan upaya yang telah dilakukan.

2. Pekerjaan itu sendiri, meliputi :

a. Kondisi sekitar tempat karyawan bekerja. 
b. Kelengkapan saarana pekerjaan yag diberikan pihak perusahaan. $c$. Keamanan lingkungan kerja.

3. Pengawasan, meliputi :

a. Pemberian petunjuk yang sesuai dengan standar kerja.

b. Penerapan peraturan kerja.

4. Peluang promosi, meliputi :

a. Kesempatan peningkatan kualitas.

b. Kesempatan mengembangkan karir.

5. Kelompok kerja, meliputi :

a. Hubungan dengan rekan kerja.

b. Kekompakan dengan rekan kerja.

C. Suasana yang ada dalam kelompok kerja.

6. Kondisi kerja, meliputi :

a. Kesesuaian pekerjaan dengan kemampuan.

b. Jenis pekerjaan yang dirasa karyawan menarik dan menantang.

\section{B. Prosedur Pengumpulan Data}

Prosedur pengumpulan data dalam penelitian ini dilakukan dengan cara:

1. Studi kepustakaan, yakni dengan mempelajari dan mengumpulkan teoriteori dari berbagai literatur dan buku bacaan lain yang berkaitan dengan permasalahan yang sedang dibahas dalam penelitian ini.

2. Penelitian pendahuluan, yaitu dengan mengadakan peninjauan dan penelitian secara umum, untuk mendapatkan informasi dan mengetahui permasalahan yang akan diangkat dalam penelitian ini.

3. Penyebaran kuesioner, yaitu dilakukan dengan cara menyebarkan kuesioner kepada karyawan Waroeng Steak \& Shake dengan mengajukan daftar pertanyaan secara singkat mengenai topik pembahasan penelitian ini, kemudian dilanjutkan dengan mengolah dan menganalisa data tersebut dengan metode statistik.

\section{Teknik Analisa Data}

Model analisis yang digunakan dalam penelitian ini berbentuk regresi linier sederhana (linier simple regression). Model analisis ini digunakan untuk mengetahui pengaruh variabel independen terhadap variabel dependen. Analisis dilakukan dengan menggunakan metode kuantitatif regresi linier sederhana, kemudian dilakukan pengujian hipotesis. Untuk membuktikan hipotesis penelitian, dapat dilakukan dengan uji t.

\section{HASIL PENELITIAN DAN PEMBAHASAN}

A. Hasil Analisis Regresi Linear Sederhana Tabel 1.

Hasil Uji Regresi Linear Sederhana

\begin{tabular}{|l|l|l|l|l|}
\hline Variabel & \multicolumn{2}{|l|}{ Koefisien } & thit. & Sign. \\
\cline { 2 - 4 } & Koef. Reg. & Beta & & \\
\hline $\begin{array}{c}\text { Konstant } \\
\text { a }\end{array}$ & 0,929 & & 1,600 & 0,120 \\
\hline $\begin{array}{l}\text { Etos Kerja } \\
\text { slam }\end{array}$ & 0,684 & 0,650 & 4,763 & 0,000 \\
\hline $\begin{array}{l}\text { Multiple } R=0.650 a \quad F H i t u n g \\
N=33 \quad R \text { Sauare }=0,423 \text { Sian }=\end{array}$ \\
\hline
\end{tabular}


Nilai dari koefisien determinasi dari hasil regresi pada penelitian ini adalah 0,423 yang berarti bahwa sebesar 42,3 \% kepuasan kerja (variabel tergantung) mampu dijelaskan oleh etos kerja Islam (variabel bebas) sedangkan sisanya sebesar 57,7 \% dijelaskan oleh variabel lain yang tidak dimasukkan dalam model (faktor galat).

Berdasarkan hasil analisis regresi linear sederhana yang dilakukan pada penelitian ini diperoleh nilai koefisien korelasi berganda atau Multiple (R) sebesar 0,650. Nilai R sebesar

0,650 menunjukkan adanya hubungan yang cukup tinggi antara variabel bebas $(X)$ dengan variabel tergantung $(Y)$.

\section{B. Uji Hipotesis}

1. Uji †

Pengujian hipotesis koefisien regresi secara parsial (uji t) ditunjukkan untuk mengetahui pengaruh variabel bebas secara parsial terhadap variabel tergantung dalam satu model. Hasil uji parsial dipaparkan selengkapnya pada Tabel berikut:

Tabel 2.

Hasil Uji Regresi Secara Parsial (Uji †)

Berdasarkan Tabel 4.12 tersebut, menunjukan bahwa nilai uji $\dagger$ variabel etos kerja Islami $(X)$ sebesar 4,763 dengan tingkat signifikasi 0,000 . Nilai signifikasi ini lebih kecil dari 0,05 , sehingga dapat ditarik kesimpulan, yaitu variabel etos kerja Islami (X) mempunyai pengaruh terhadap kepuasan kerja karyawan Waroeng Steak \& Shake di Surabaya (Y).

\section{Pembahasan}

Berdasarkan hasil analisis koefisien korelasi dalam penelitian ini, disebutkan bahwa variabel tanggung jawab sosial Islam (X) berpengaruh signifikan dengan variabel kinerja Islam (Y). Hubungan antar variabel juga menunjukkan tanda positif. Hubungan yang positif antar variabel tersebut dapat diartikan bahwa setiap peningkatan variabel bebas akan berpengaruh terhadap peningkatan variabel tergantung, begitu pula sebaliknya setiap penurunan variabel bebas akan berpengaruh pula pada penurunan variabel tergantung.

Berdasarkan hasil pengolahan data dari 33 responden, menunjukan bahwa secara keseluruhan rata-rata tanggapan responden pada etos kerja Islam termasuk tinggi, dengan rata-rata tanggapan responden yang termasuk sangat tinggi hanya sebanyak 4 indikator yang meliputi :

1. Memiliki kesegaran apresiasi terhadap alam dan kehidupan (X1.5).

2. Menyukai efisiensi kerja (X1.9).

3. Memiliki sifat demokratis (X1.13).

4. Percaya pada potensi insani

\begin{tabular}{|l|l|l|}
\hline Variabel & T & $\begin{array}{l}\text { Tingkat } \\
\text { signifikansi }\end{array}$ \\
\hline $\begin{array}{l}\text { Etos Kerja } \\
\text { Islami }\end{array}$ & 4,763 & 0,000 \\
\hline
\end{tabular}

tugasnya, bertawakkal kepada Allah SWT (X1.15).

Dan rata-rata tanggapan responden yang termasuk tinggi sebanyak 12 indikator yang meliputi : 
1. Dapat menerima kenyataan berkenaan dengan diri sendiri, orang lain, dan alam

(X1.1).

2. Berperilaku wajar tidak dibuat-buat (X1.2).

3. Berpendirian teguh dan tidak mudah terpengaruh (X1.3).

4. Konsentrasi perbuatan tidak pada ego, melainkan pada kewajiban dan rasa tanggung jawab (X1.4).

5. Mempunyai kehidupan motivasi yang terutama digerakan oleh motivasi ibadah dan hasrat memperoleh kehidupan surgawi di akhirat kelak (X1.6).

6. Pernah atau sering mengalami pengalaman puncak (X1.7).

7. Mampu membedakan antara tujuan benar dan salah, baik dan buruk (X1.8).

8. Menyukai efektivitas kerja (X1.10).

9. Mempunyai disiplin pribadi (X1.11).

10. Memiliki jiwa sosial (X1.12).

11. Mengembangkan kreativitas (X1.14).

12. Mengembangkan sikap hidup kritis konstruktif (X1.16).

Oleh karena itu, dari hasil analisis data tersebut dapat menunjukan bahwa etos kerja Islam termasuk tinggi.

Uji yang dilakukan yaitu uji † untuk mengetahui apakah variabel-variabel tersebut memiliki pengaruh yang signifikan. Hasil uji regresi menunjukkan besar nilai $\dagger$ sebesar 4,763 dengan tingkat signifikan < 0,05, yaitu 0,000. Hasil tersebut menunjukan bahwa tinggi rendahnya kepuasan kerja karyawan Waroeng Steak \& Shake di Surabaya salah satunya dipengaruhi oleh faktor etos kerja Islam. Dengan demikian, hasil analisis ini menunjukan bahwa hipotesis dapat diterima, artinya etos kerja Islami mempunyai pengaruh positif yang signifikan terhadap kepuasan kerja karyawan Waroeng Steak \& Shake di Surabaya.

Adapun besarnya nilai koefisien determinasi (R2), yaitu sebesar 0,423, yang berarti bahwa etos kerja Islam mempunyai pengaruh terhadap kepuasan kerja karyawan Waroeng Steak \& Shake di Surabaya sebesar 42,3\%. Sedangkan sisanya, yaitu sebesar $57,7 \%$ dipengaruhi variabel lain yang tidak diteliti.

Selain itu hasil penelitian sebelumnya yang mendukung adalah penelitian dari Marri (2012) yang berjudul Dampak Etos Kerja Islam Terhadap Kepuasan Kerja dan Organisasi Komitmen: Studi Kasus Sektor Pertanian Pakistan menyatakan bahwa hubungan antara Islamic Work Ethics letos kerja Islami) dan kepuasan kerja adalah positif dan sangat signifikan, hasilnya menunjukkan bahwa jika etos kerja Islam tersebut diikuti seacara baik dan benar maka karyawan akan puas dengan pekerjaan yang mereka lakukan. Semakin tinggi

etos kerja Islami seorang karyawan, maka akan semakin tinggi kepuasan kerja yang didapat.

Dengan pengembangan etos kerja Islami yang ada dalam diri pribadi setiap manusia, semua yang dilaksanakan dapat terwujud sesuai nilai 
moral yang dimilikinya. Karenanya, etos kerja Islami bukanlah sekedar kepribadian atau sikap, melainkan lebi h mendalam lagi, karena didalamnya terdapat martabat, harga diri dan jati diri dari seorang tersebut.

Yousef (1989:515) menjelaskan bahwa etos kerja Islam memberikan tekanan pada kerja yang rata-rata dapat membantu pertumbuhan atau kemajuan personal, penghargaan terhadap diri sendiri atau orang lain, kepuasan kerja, dan pemberdayaan diri. Selain itu tekanan untuk bekerja secara kreatif dapat sebagai sumber dari kesenangan dan prestasi. Bekerja keras dipandang sebagai kebaikan, dan barang siapa yang bekerja keras maka akan lebih mungkin mendapatkan kemajuan dalam hidupnya dan sebaliknya, jika tidak mau bekerja keras maka akan dipandang sebagai penyebab kegagalan dalam hidup.

\section{KESIMPULAN DAN SARAN}

\section{A. Simpulan}

Simpulan penelitian Pengaruh Ełos Kerja Islam terhadap Kepuasan Kerja Karyawan Waroeng Steak \& Shake di Surabaya adalah tingkat etos kerja Islam berpengaruh langsung, positif, dan signifikan terhadap kepuasan kerja karyawan Waroeng Steak \& Shake di Surabaya. Hal ini menunjukkan bahwa hipotesis yang menyatakan etos kerja Islam berpengaruh signifikan terhadap kepuasan kerja karyawan
Waroeng Steak \& Shake di Surabaya adalah diterima. Secara teoritis temuan ini mengandung makna bahwa etos kerja Islam merupakan instrumen penting untung memenuhi kepuasan kerja karyawan Waroeng Steak \& Shake di Surabaya. Semakin tinggi tingkat etos kerja Islam, akan semakin meningkat pula kepuasan kerja karyawan.

\section{B. Saran}

Saran yang direkomendasikan setelah penelitian "Pengaruh Etos Kerja Islam Terhadap Kepuasan Kerja Karyawan Pada Waroeng Steak \& Shake Surabaya" adalah:

1. Untuk Waroeng Steak \& Shake cabang Surabaya

a. Sesuai dengan analisis data deskripsi variabel etos kerja Islam yaitu mempunyai kehidupan motivasi yang terutama digerakkan oleh motivasi ibadah dan hasrat memperoleh kehidupan surgawi di akhirat kelak (X1.6) dengan nilai mean terendah, maka dapat disarankan kepada karyawan Waroeng Steak \& Shake di Surabaya agar meningkatkan kehidupan motivasi yang terutama digerakan oleh motivasi ibadah dan hasrat memperoleh kehidupan surgawi di akhirat kelak. Hal ini disarankan agar karyawan Waroeng Steak \& Shake dapat memiliki etos kerja Islami yang tinggi dengan tujuan agar kepuasan kerja dapat terpenuhi.

b. Sesuai dengan analisis data deskripsi variabel kepuasan kerja yaitu kesesuaian gaji dengan upaya yang 
telah dilakukan (Y1.3) dengan nilai mean terendah, maka dapat disarankan kepada pihak Waroeng Steak \& Shake di Surabaya hendaknya kesesuaian gaji dengan upaya yang telah dilakukan oleh karyawan lebih diperhatikan. Hal ini disarankan agar kepuasan kerja karyawan dapat termaksimalkan.

2. Untuk Penelitian Selanjutnya

Diharapkan penelitian ini dapat digunakan sebagai bahan acuan untuk melakukakan penelitian selanjutnya. Peneliti menyadari bahwa penelitian ini memiliki banyak keterbatasan, karena variabel eksogen yang diteliti belum mampu mencangkup seluruh faktor-faktor yang dapat mempengaruhi kepuasan kerja. Oleh karena itu, keterbatasan penelitian ini akan memberikan peluang bagi penelitian selanjutnya untuk melakukan pengembangan dan peningkatan etos kerja Islami secara lebih luas. Penelitian dengan menguji dan menambahkan variabel intervening diantara variabel etos kerja Islami dan kepuasan kerja akan menjadi agenda penelitian yang menarik untuk diteliti lebih jauh. Sehingga akan menambah wawasan yang lebih luas terkait dengan manajemen sumber daya insani.

\section{DAFTAR PUSTAKA}

Ahmad, Mustaq. 2001. Etika Bisnis Dalam Islam. Jakarta: Pustaka Al-Kautsar.

Ali, J.A. and Al-Owaihan, A. 2008. "Islamic work ethic: a critical review" Cross Cultural
Management an International Journal. Vol. 15 No. 1

As'ad, Mohamad. 2004. Psikologi Industri.Yogyakarta: Liberty. Asifudin, Ahmad. 2006. Ełos Kerja Islami. Yogyakarta : UII Press.

Azis Slamet Wiyono dan M. Wahyuddin, 2005, Studi Tentang Kualitas Pelayanan dan Kepuasan Konsumen di Rumah Sakit Islam Manisrenggo Klaten, Program Pascasarjana Universitas Muhammadiyah Surakarta Jalan A. Yani, Tromol Pos 1, Pabelan, Surakarta 57102.

Azizi, Moh Ali. 2005. Dakwah Pemberdayaan Masyarakat Paradikma Aksi metodologi.Yogyakarta : Pustaka Pesantren

Blum, M.L. 1956. Industrial Psichology and Its Socal Foundation. New York: Harper and Row

Brown SP, Leigh TW. 1996. A New Look at Psyshological Climate and Its Relationship to Job

Involvement, Effort and Performance. Journal of Applied Psychology. 81:358-368.

Departemen Agama RI. 2012. Al-Qur'an dan Terjemahannya dengan Transliterasi. Semarang: PT Karya Toha Putra.

Fakultas Ekonomi Universitas Airlangga. 2009. Pedoman Pelaksanaan Pendidikan Fakultas 
Ekonomi Universitas Airlangga. Surabaya:

Fakultas Ekonomi.

Hamzah, Ya'kub 1983. Etika Islam. Bandung: CV. Diponegoro

Hasibuan, Malayu. 2001. Manajemen Sumber Daya Manusia:Pengertian Dasar, Pengertian, dan Masalah. Jakarta: PT. Toko Gunung Agung.

Hayati, Keumala. 2012. Islamic Work Ethic: The Role of Intrinsic Motivation, Job Satisfaction, Organizational Commitment and JobPerformance. Procedia Social and Behavioral Sciences 65 ( 2012 ) $272-277$

Herman Soewardi. 2004. Sosiologi: Membangkitkan Karsa Umat. Tumpuan Utama Bagi Pembangunan. Bakti Mandiri. Bandung

Jewell, L.N. dan Siegall Mac. 1988. Psikologi Industri Organisasi Modern. Edisi Kedua. Arcan. Lambert, E \& Hogan, N 2009, "The importance of job satisfaction and organisational commitment in shaping turnover intent", Criminal Justice Review, vol. 34, no. 1, pp. 96-118.

Mangkunegara, Anwar Prabowo, 2005. Perencanaan dan Pengembangan Sumber Daya Manusia. Bandung: PT. Refika Aditama.

Marri, Muhammad Yousuf Khan. 2012. The Impact of Islamic Work Ethics on
Job Satisfaction and Organizational Commitment: A Study of Agriculture Sector of Pakistan. International Journal of Business and Behavioral Sciences Vol. 2, No.12; December 2012

Robbins, S.P. 2006. Perilaku organisasi. Edisi Enam. Alih bahasa oleh Tim Indeks. Jakarta: PT.Indeks.

Sinamo, Jansen. 2005. Delapan Ełos Kerja Profesional; Navigator Anda Menuju Sukses. Bogor: Grafika Mardi Yuana.

Sutrisno, Hadi. 2000. Metodologi Research. Jilid 2. Yogyakarta: Andi.

Tasmara, Toto. 2002. Membudayakan Ełos Kerja Islami. Jakarta : Gema Insan Press.

Wexley, K.N. \& Yukl, G.A. 1997. Organizational Behaviour and Personnel Psychology. Home Wood, Illinois: Richard D. Irwin, Inc. Yousef, Darwish A. 2000. Organizational Commitment As Amediator Of The Relaationship Between Islamic Work Ethic and Attitudes Toward Organizational Change. Journal Of Human Relation, Vol. 53, No. 4, September. 